\title{
Penguatan Peran Perguruan Tinggi Islam Dalam Mendorong Pengembangan Lembaga Keuangan Syariah di Indonesia
}

\author{
Murtiadi Awaluddin \\ Fakultas Ekonomi dan Bisnis Islam UIN Alauddin Makassar \\ Jalan HM Yasin Limpo No.36, Samata-Gowa \\ E-mail : murtiadi.awaluddin@uin-alauddin.ac.id
}

Diterima: 23 November 2018; Direvisi: 5 Desember 2018; Diterbitkan: 22 Desember 2018

\begin{abstract}
Abstrak,
Tujuan dari penelitian ini adalah untuk merumuskan strategi yang tepat dalam memperkuat peran universitas Islam dalam mendorong pengembangan lembaga keuangan Islam di Indonesia. Peneliti mengambil objek penelitian pada tiga PTKI di Makassar. Jenis penelitian adalah analisis kualitatif dengan pendekatan phenomologis dengan menggunakan data primer dalam bentuk pernyataan dan sikap, dan data sekunder dalam bentuk literatur yang relevan dan mendukung diskusi penelitian, dokumentasi. Teknik pengumpulan data berupa observasi, dokumentasi, wawancara langsung dengan pihak-pihak terkait. Kemudian teknik pengolahan dan analisis data dilakukan melalui empat tahap, yaitu: pengumpulan data, reduksi data, penyajian data, dan penarikan kesimpulan. Hasil penelitian menunjukkan bahwa Universitas Islam memiliki potensi dan peran besar dalam mendukung pengembangan lembaga keuangan syariah di Indonesia baik dalam hal kebutuhan sumber daya manusia, maupun potensi pemasaran produk keuangan syariah
\end{abstract}

Kata Kunci: Perguruan Tinggi Islam, Lembaga Keuangan, Penguatan

\begin{abstract}
,
The purpose of this study is to formulate appropriate strategies in strengthening the role of Islamic universities in encouraging the development of Islamic financial institutions in Indonesia. Researchers took the object of research on three PTKI in Makassar. The type of research is qualitative analysis of phenomological approach. Data is obtained from primary data in the form of statements and attitudes, then secondary data in the form of relevant literature and support the discussion of research, documentation. Techniques of collecting data in the form of observation, documentation, interview (Interview) directly with the parties concerned. Then the technique of processing and data analysis is done through four stages, namely: data collection, data reduction, data presentation, and conclusion. The result shows that Islamic University has great potential and role in supporting the development of Shariah financial institutions in Indonesia both in terms of human resource needs, as well as the marketing potential of syariah financial products.
\end{abstract}

Keywords: Islamic University, Financial Institution, Strengthening 


\section{PENDAHULUAN}

Indonesia merupakan negara dengan populasi Muslim terbesar di dunia yang terletak di wilayah Asia Tenggara. Dengan laju pertumbuhan penduduk rata-rata per tahun yang mencapai angka sekitar 4 juta orang sesuai data BPS, dapat dipastikan Indonesia ini tetap menjadi negara dengan populasi Muslim terbanyak sampai beberapa tahun ke depan. Namun, meskipun jumlah muslim terbesar di dunia, pangsa pasar industri keuangan syariah di Indonesia masih relatif rendah, contoh untuk perbankan syariah baru menyentuh angka tiga persen di akhir bulan Desember 2010 (Abduh, 2011).

Pada tahun 2017 berdasarkan data dari Bank Indonesia pangsa pasar perbankan syariah di Indonesia hanya mampu di angka 5,3 persen terhadap seluruh aset industri perbankan nasional. Jadi untuk 7 tahun hanya bisa bertambah 2.3 persen. Dari data OJK 2017, secara kelembagaan, kini perbankan syariah memiliki 13 Bank Umum Syariah (BUS), 21 Unit Usaha Syariah (UUS) dan 167 Bank Pembiayaan Rakyat Syariah (BPRS). Meskipun sudah banyak pencapaian yang dihasilkan, perkembangan industri perbankan syariah saat ini cenderung stagnan. Pangsa pasar perbankan syariah di Indonesia masih tergolong rendah dan belum sesuai harapan jika dibandingkan dengan potensinya.

Dengan demografi penduduk Muslim terbesar di dunia, seharusnya perbankan syariah di Indonesia dapat menjadi pilihan utama masyarakat. Padahal perbankan syariah muncul sebagai alternatif dari bank-bank konvensional yang selama ini tidak sesuai dengan kaidah Islam. Sistem bunga yang ada pada bank-bank konvensional di dalam fiqh dianggap riba dan haram hukumnya bagi umat Islam seperti dalam Alquran surat Al Baqarah ayat 278.

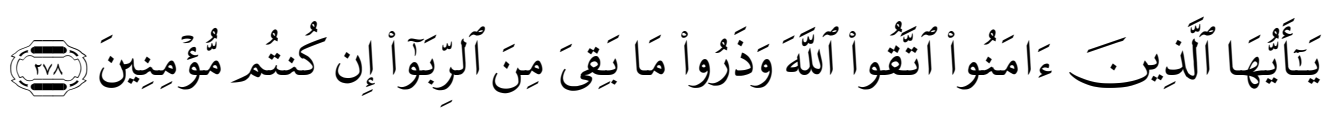

Terjemahnya,

"Hai orang-orang yang beriman, bertakwalah kepada Allah dan tinggalkanlah sisa riba (yang belum dipungut), jika kamu orang yang beriman.”

Populasi muslim di Indonesia berjumlah lebih dari 85 persen dari total penduduk Indonesia. Ini menjadi alasan utama, sebenarnya Indonesia adalah pasar yang menjanjikan untuk keuangan syariah seperti Perbankan Syariah, Industri Keungan Non Bank (IKNB) Syariah, termasuk pasar modal syariah. Namun, sayangnya potensi yang begitu besar itu belum dapat dimanfaatkan dengan optimal. Saat ini, Indonesia berada di posisi ke-9 sebagai negara dengan aset keuangan syariah terbesar. Berdasarkan data dari Roadmap Pengembangan Keuangan Syariah Indonesia 2017-2019, tampak dari tahun 2013 hingga tahun 2016 total aset keuangan syariah meningkat, meskipun pertumbuhannya sempat 
mengalami penurunan di tahun 2014, yaitu pertumbuhannya sebesar 18,17\% jika dibanding tahun 2013 yang tumbuh sebesar 26,21\% dari tahun sebelumnya. Pada Desember 2016, total aset keuangan syariah Indonesia (tidak termasuk saham syariah) mencapai Rp889,28 triliun atau sekitar USD66,2 miliar, yang terdiri dari a. Industri perbankan syariah sebesar 41,12\% dengan nilai sebesar Rp365,65 triliun; b. Sukuk negara dan sukuk korporasi sebesar 47,59\% dengan nilai sebesar Rp432,25 triliun; c. Reksa dana syariah sebesar 1,68\% dengan nilai sebesar Rp14,91 triliun; dan d. IKNB syariah (asuransi syariah, pembiayaan syariah, lembaga non bank syariah lainnya) sebesar 9,61\% dengan nilai sebesar Rp85,48 triliun.

Masyarakat Indonesia yang sebagian besar adalah umat Islam tentu saja tidak akan menolak dengan kehadiran perbankan syariah di Indonesia. Bahkan di Indonesia perkembangan sistem perbankan dan keuangan syariah semakin kuat dengan ditetapkannya hukum-hukum dasar operasional melalui Undang-Undang No. 21/2008 tentang "Perbankan Syariah". Sebuah riset lapangan yang mengkaji sisi kualitas layanan dalam rangka Islamic Banking Quality Award (IBQA) 2005 dengan metode mystery shopping yang dilakukan di Indonesia, menunjukkan bahwa adanya tingkat kepuasan nasabah yang tinggi terhadap bankbank syariah, namun ada di antara bank-bank yang merupakan unit syariah dari bank-bank konvensional, kualitas layanan cabang syariahnya masih jauh di bawah kualitas layanan konvensionalnya. Minimnya product knowledge staf mereka akan produk-produk syariah, dan minimnya fasilitas mushala merupakan kelemahan yang lazim ditemui pada bank-bank tersebut (Karim,2005). Penelitian Mursyid (2011) dan Masruroh (2015) tentang preferensi menabung di bank syariah menyebutkan hasil yang berbeda. Hasil penelitian Mursyid menunjukkan bahwa penghasilan mempunyai pengaruh yang tidak signifikan, sedangkan religiusitas berpengaruh signifikan. Sementara hasil penelitian Masruroh menyebutkan disposible income (penghasilan) berpengaruh signifikan jika dimoderasi dengan variabel religiusitas, namun semua faktor - faktor tersebut dipercaya berpengaruh terhadap preferensi menabung di bank syariah. Penelitian Lestari (2015) menjelaskan bahwa pengaruh kepercayaan terhadap preferensi utama menabung di bank syariah adalah pengetahuan ilmiah. Pengaruh kualitas pelayanan terhadap preferensi utama menabung di bank syariah adalah kemudahan fasilitas. Penelitian Muti ’ah (2015) yang berkaitan dengan motif ekonomi seseorang untuk menabung di bank syariah menyebutkan bahwa motif rasional dan motif emosional berpengaruh terhadap pengambilan keputusan memilih jasa perbankan syariah. Motif rasional berkaitan dengan keuntungan dari sistem bagi hasil yang diberikan bank syariah sedangkan motif emosional berkaitan dengan perintah agama yaitu larangan riba.

Data dari Forlap Dikti tahun 2018 menyatakan bahwa institusi perguruan tinggi islam dijadikan sebagai cakupan lingkup penelitian yang terdaftar mencapai 761 unit. Angka ini 
didominasi oleh perguruan tinggi dengan status sekolah tinggi yang mencapai 639 unit. Sedangkan perguruan tinggi dengan status institut, yakni 105 uunit. Sisanya adalah perguruan tinggi universitas yaitu hanya 17 unit. Dari jumlah institusi tersebut terdapat kurang lebih 6 juta jumlah mahasiswa dengan 380.000 dosen ditambah staf atau tenaga kependidikan. Angka ini merupakan pasar potensial bagi produk perbankan syariah baik untuk produk tabungan, kredit dan transaksi keuangan lainnya, selain itu dalam institusi perguruan tinggi terdapat lembaga keuangan lain diantaranya koperasi pegawai, koperasi mahasiswa dan BMT bagi institusi dari Kementerian Agama. Selain itu karakteristik pasar akademisi sangat mudah untuk dilakukan literasi keuangan berbasis syariah. Alasan berikutnya adalah Institusi Perguruan tinggi adalah merupakan bahan baku sumber daya insani Perbankan Syariah dan terakhir institusi perguruan tinggi dapat menjadi sumber peningkatan SDM bagi karyawan bank syariah. Besarnya potensi yang dapat dikelola secara optimal oleh industri perbankan syariah sehingga sangat perlu dilakukan suatu kajian mendalam tentang peran perguruan tinggi dalam mendorong pengembangan industri perbankan syariah berbasis keungulan kompetitif di indonesia.

Berbagai kajian ilmiah telah dilakukan baik praktisi maupun akademisi, sehingga mulai tampak jelas sumber permasalahan penyebab industri perbankan syariah kurang meningkat secara signifikan tetapi masih saja peningkatan market share belum mampu melampaui 5 persen. sehingga ini dapat dianggap sebagai kejadian luar biasa. Dan untuk menangani kejadian luar biasa tersebut diperlukan kajian inovasi yang luar biasa juga yaitu dirumuskannya model pengembangan industri perbankan syariah terbarukan secara massifikasi melalui penguatan peran institusi perguruan tinggi Islam dalam mendorong pengembangan lembaga keuangan syariah di indonesia. Adapun tujuan penelitian ini adalah untuk merumuskan strategi yang tepat dalam memperkuat peranan perguruan tinggi dalam mendorong pengembangan lembaga keuangan syariah di Indonesia.

\section{TINJAUAN TEORITIK}

\section{Lembaga Keuangan Syariah}

Dalam Undang-Undang Republik Indonesia Tahun 1992 tantang Perbankan Syariah bahwa Lembaga Keuangan Syariah adalah merupakan badan atau lemabaga yang kegiatannya menarik dana masyarakat dan menyalurkannya kepada masyarakat berdasarkan prinsip Syariah. Lembaga Keuangan Syariah adalah sebagai bagian dari sistem ekonomi Syariah, dalam menjalankan bisnis dan usahanya juga tidak terlepas dari saringan Syariah.22 Maka dari itu lembaga ini dalam transaksinya tidak mungkin mengenal istilah bunga dalam artian tidak memakai sistem bunga tapi menggunakan sistem bagi hasil dan tidak mungkin 
menyalurkan dananya kepada usaha-usaha yang di dalamnya mengandung hal-hal yang bertentangan dengan prinsip-prinsip Syariah serta proyek-proyek yang menimbulkan kemudharratan bagi masyarakat luas.

Ditinjau dari segi tugas dan fungsinya, Lembaga Keuangan Syariah dapat dibedakan kedalam dua macam, pertama; lembaga keuangan dalam bentuk bank, yaitu lembaga keuangan yang dalam melaksanakan akad (transaksi) ekonominya terutama menarik dan menyalurkan uang dari dan kepada masyarakat dengan menggunakan sistem Syariah atau hukum Islam. (Amin Suma, 2008) . Kedua; lembaga keuangan non bank, yaitu semua badan yang melakukan kegiatan di bidang keuangan, yang secara langsung atau tidak langsung menghimpun dana terutama dengan jalan mengeluarkan kertas berharga dan menyalurkannya kepada masyarakat guna membiayai investasi perusahaan-perusahaan.

\section{Kebijakan Pengembangan Perbankan Syariah Di Indonesia}

Pengembangan perbankan syariah diarahkan untuk memberikan kemaslahatan terbesar bagi masyarakat dan berkontribusi secara optimal bagi perekonomian nasional. Oleh karena itu, maka arah pengembangan perbankan syariah nasional selalu mengacu kepada rencana-rencana strategis lainnya, seperti Arsitektur Perbankan Indonesia (API), Arsitektur Sistem Keuangan Indonesia (ASKI), serta Rencana Pembangunan Jangka Menengah Nasional (RPJMN) dan Rencana Pembangunan Jangka Panjang Nasional (RPJPN). Dengan demikian upaya pengembangan perbankan syariah merupakan bagian dan kegiatan yang mendukung pencapaian rencana strategis dalam skala yang lebih besar pada tingkat nasional.

Dalam jangka pendek, perbankan syariah nasional lebih diarahkan pada pelayanan pasar domestik yang potensinya masih sangat besar. Dengan kata lain, perbankan Syariah nasional harus sanggup untuk menjadi pemain domestik akan tetapi memiliki kualitas layanan dan kinerja yang bertaraf internasional. Pada akhirnya, sistem perbankan syariah yang ingin diwujudkan oleh Bank Indonesia adalah perbankan syariah yang modern, yang bersifat universal, terbuka bagi seluruh masyarakat Indonesia tanpa terkecuali. Sebuah sistem perbankan yang menghadirkan bentuk-bentuk aplikatif dari konsep ekonomi syariah yang dirumuskan secara bijaksana, dalam konteks kekinian permasalahan yang sedang dihadapi oleh bangsa Indonesia, dan dengan tetap memperhatikan kondisi sosio-kultural di dalam mana bangsa ini menuliskan perjalanan sejarahnya. (Bank Indonesia,2012).

\section{Pembangunan Literasi Keuangan Syariah}

Financial literacy (literasi keuangan) merupakan salah satu program strategis yang menjadi bagian dari upaya pemerintah dan masyarakat di berbagai negara dalam 
mewujudkan masyarakat yang melek mengenai jasa keuangan. Pengalaman dari berbagai negara membuktikan bahwa literasi keuangan telah menjadi program nasional untuk meningkatkan kemakmuran dan kesejahteraan masyarakatnya, mengingat literasi keuangan memiliki berbagai manfaat.

Program literasi keuangan syariah memiliki manfaat yang besar antara lain: a. Masyarakat mampu memilih dan memanfaatkan produk dan jasa keuangan syariah yang sesuai kebutuhan mereka. b. Masyarakat mampu melakukan perencanaan keuangan (financial planning) secara syariah dengan lebih baik. c. Masyarakat terhindar dari aktivitas investasi pada instrumen keuangan yang tidak jelas (bodong). d. Masyarakat mendapat pemahaman mengenai manfaat dan risiko produk serta jasa keuangan syariah.

\section{METODE PENELITIAN}

Penelitian ini menggunakan metode kualitatif dengan studi fenomenologi. Data yang digunakan dalam penelitian ini adalah data subyek yaitu data berupa opini, sikap, pengalaman atau karakteristik seseorang atau sekelompok orang yang menjadi subyek penelitian (responden). Dalam hal ini data primer didapat dari dosen dan praktisi perbankan syariah sebagai responden. Menggunakan metode survei, yaitu menggunakan metode wawancara langsung dengan responden dan dengan menggunakan daftar kuesioner. Adapun yang termasuk dalam kategori data yang didapat ini berhubungan dengan variabel yang akan diteliti. Subjek penelitian yang dipilih adalah dosen dan pejabat institusi pada PTKI di Makassar (Universitas Islam Negeri Alauddin Makassar, Universitas Islam Makassar serta Universitas Muhammadiyah Makassar) dan praktisi lembaga keuangan (perbankan syariah, pegadaian syariah, dan asuransi syariah).

Analisis data dalam sebuah penelitian sangat dibutuhkan bahkan merupakan bagian yang sangat menentukan dari beberapa langkah penelitian sebelumnya. Dalam penelitian kualitatif, analisis data harus seiring dengan pengumpulan fakta-fakta di lapangan, dengan demikain analisis data dapat dilakukan sepanjang proses penelitian dengan menggunakan tehnik analisa sebagai berikut:

Reduksi data meliputi: meringkas data, mengkode, menelusur tema, membuat gugusgugus. Penyajian data adalah kegiatan ketika sekumpulan informasi disusun, sehingga memberi kemungkinan adanya penarikan kesimpulan dan pengambilan tindakan. Bentuk penyajian data kualitatif, dapat berupa teks naratif, maupun matrik, grafik, jaringan dan bagan. Upaya penarikan kesimpulan atau verifikasi dilakukan peneliti secara terus-menerus selama berada di lapangan. Dari permulaan pengumpulan data, mulai mencari arti benda- 
benda, mencatat keteraturan pola-pola (dalam catatat teori), penjelasan-penjelasan, konfigurasi-konfigurasi yang mungkin, alur sebab akibat.

\section{HASIL DAN PEMBAHASAN}

\section{Peranan Perguruan Tinggi di Masyarakat}

Perguruan Tinggi sebagai salah satu institusi yang ada di Indonesia mengemban amanah yaitu harus mengupayakan dan menjadikan dirinya sebagai pusat pengembangan dan penyebarluasan IPTEK serta mengupayakan penggunaannya untuk meningkatkan taraf kehidupan masyarakat.

Keberadaan Perguruan Tinggi mempunyai kedudukan dan fungsi penting dalam perkembangan suatu masyarakat. Proses perubahan sosial (social change) di masyarakat itu benar-benar terwujud dalam peran yang nyata. Pada umumnya peran Perguruan Tinggi diharapkan tertuang dalam Tri Dharma Perguruan Tinggi, yaitu: Dharma pendidikan, penelitian, dan pengabdian masyarakat. Dengan dharma pendidikan perguruan diharapkan melakukan peran pencerdasan masyarakat dan transmisi budaya. Dengan dharma penelitian, perguruan tinggi diharapkan melakukan temuan-temuan baru ilmu pengetahuan dan inovasi kebudayaan. Dengan dharma pengabdian masyarakat, perguruan tinggi diharapkan melakukan pelayanan masyarakat untuk ikut mempercepat proses peningkatan kesejahteraan dan kemajuan masyarakat. Melalui dharma pengabdian pada masyarakat inilah perguruan tinggi juga akan memperoleh feedback dari masyarakat tentang tingkat kemajuan dan relevansi ilmu yang dikembangkan perguruan tinggi itu.

Dalam kaitannya dengan pertumbuhan industri perbankan syariah, Perguruan Tinggi memiliki peranan sangat penting dalam mempengaruhi perubahan-perubahan suatu masyarakat. Peran dan fungsi Perguruan Tinggi dapat diwujudkan dalam bentuk membangunan gerakan pembelajaran masyarakat (literasi) untuk mendorong segera terciptanya transformasi keilmuan.

Perguruan Tinggi dapat berperan lebih progresif dalam mempengaruhi perubahan masyarakat serta sistematis dan berdampak luas dimasa-masa mendatang. Untuk itu kedekatan Perguruan Tinggi dan masyarakat harus diusahakan melalui program kemitraan kelompok-kelompok mahasiswa dan masyarakat dengan Perguruan Tinggi, sehingga proses literasi keuangan syariah semakin efektif.

Perguruan Tinggi dituntut untuk menentukan dan memilih kebijakan yang benarbenar strategis bagi perubahan-perubahan yang ada di masyarakat. Maka saatnyalah, perguruan tinggi terlibat dalam perumusan kebijakan pengembangan industri yang akan 
diambil pemerintah daerah. Di sisi lain, perguruan tinggi harus terus memperbanyak riset, baik rekayasa teknologi maupun rekayasa spesifik lainnya. Dengan cara demikian, perguruan tinggi pantas dilibatkan dalam mendesain rencana pembangunan daerah dan memonitor evaluasi pelaksanaan program pembangunan

\section{Perguruan Tinggi Keagamaan Islam (PTKI) sebagai Sumber Daya Insani Bagi Lembaga Keuangan Syariah}

Pada sebuah organisasi, manajemen dipahami sebagai suatu proses penentuan dan pencapaian tujuan melalui pelaksanaan empat fungsi dasar, yaitu: (1) perencanaan (planning/at-takhthiith); (2) pengorganisasian (organizing/at-tanziem), (3) pengarahan (actuating/at-tansiiq); dan (4) pengendalian (controlling/al-muraqabah) (Usman, 2015). Adapun yang dimaksud dengan sumber daya insani didefinisikan sebagai orang orang yang ada dalam suatu organisasi yang memberikan sumbangan pemikiran dan melakukan berbagai jenis pekerjaan dalam mencapai tujuan organisasi (Sukirno dkk ,2015) Dalam kaitannya dengan lembaga keuangan syariah, Imam Ghazali menjelaskan bahwa sumber daya insani merupakan kontribusi dalam peningkatan market share perusahaan dalam semua aspek dan menjaganya untuk tetap bertahan pada kondisi yang baik yaitu yang diinginkan perusahaan (Ghazali,2012). Manajeman sumber daya insani merupakan hal yang sangat penting, karena sangat berkaitan dengan performa suatu lembaga keuangan syariah atau perusahaan dalam menghasilkan sesuatu (produk atau jasa). Sumber daya insani merupakan kunci utama dalam sebuah perusahaan sehingga menjadi sangat penting untuk diperhatikan baik itu secara individu karyawan maupun secara kelompok. Sumber daya insani harus dapat memenuhi kriteria yang dibutuhkan perusahaan.

Pada tataran teoritis dan konseptual, kita masih merasakan sangat kekurangan SDI yang benar-benar mendalami ilmu ushul fikih, fikih muamalah, qawa'id fikih dan sekaligus ilmu ekonomi keuangan modern. Kompetensi seperti ini masih sangat langka bukan saja bagi masyarakat Islam di Indonesia melainkan juga di banyak negara termasuk negara lain yang perkembangan ekonomi Islamnya cukup pesat. Kebanyakan SDI perbankan syariah saat ini adalah mereka yang fasih berbicara tentang ilmu ekonomi keuangan kontemporer, tetapi awam dalam ushul fiqh atau fiqh muamalah. Sebaliknya banyak pakar yang mahir dalam fikih dan usul fiqh tetapi kurang memahami tentang ilmu ekonomi keuangan, padahal kompetensi seperti itulah yang sangat dibutuhkan sebagai sumberdaya insani bagi lembaga keuangan syariah. Berkaitan dengan kualifikasi yang dibutuhkan oleh industri keuangan syariah, Bank Indonesia merincinya dalam beberapa bentuk kualifikasi yang harus dimiliki para SDI industri syariah yakni (Sulasmanto, 2010) : (1) memahami nilai-nilai moral dalam aplikasi 
mualamah/ekonomi syariah. (2) memahami konsep dan tujuan ekonomi syariah. (3) memahami konsep dan aplikasi transaksi (akad) dalam muamalah ekonomi syariah. (4) mengenal dan memahami mekanisme kerja lembaga ekonomi, keuangan, perbankan, dan bisnis syariah. (5) mengetahui dan memahami mekanisme kerja dan interaksi terkait; regulator, pengawas, lembaga hukum, konsultan dalam industri keuangan, perbankan, dan bisnis syariah. (6) mengetahui dan memahami hukum dasar bail(hukum syariah (fiqh muamalah) maupun hukum positif yang berlaku. (7) menguasai bahasa sumber ilmu yakni arab dan inggris. (8) mengenal mekanisme kerja lembaga ekonomi, keuangan, dan perbankan konvensional. (9) memenuhi kompetensi perilaku.

Berbagai langkah yang dapat diambil untuk menjadikan alumni perguruan tinggi sebagai sumber daya insani siap pakai ialah adanya interkoneksi kerjasama antara pelaku lembaga keuangan syariah dan pihak lainnya diantaranya Otoritas Jasa Keuangan Syariah, Dewan Syariah, Nasional Majelis Ulama Indonesia (DSN-MUI), Ikatan Ahli Ekonomi Islam (IAEI), Masyarakat dan Ekonomi Syariah (MES), untuk bersama-sama merumuskan kurikulum akademik berbasis stakeholder. Ini dimaksudkan untuk mencetak tenaga ahli yang sesuai tuntutan industri keuangan syariah.

Kebutuhan terhadap evaluasi dan revisi kurikulum itu dilakukan dengan melihat tuntutan perkembangan duia kerja serta kebutuhan pasar khususnya industri keuangan syariah, dan yang terpenting adalah membekali para mahasiswa agar ilmu yang mereka peroleh dapat diterapkan dengan baik di dunia kerja, sehingga setiap output yang dihasilkan oleh Program Studi perbankan syariah maupun ekonomi syariah mampu bersaing dalam bursa dunia kerja yang sangat kompetitif, bahkan mampu menjadi wirausaha mandiri yang mumpuni berani menunjukkan ciri sebagai pelaku ekonomi dan bisnis syarie ah

Kondisi yang ada sekarang ini dari ketiga Perguruan tinggi islam di Makassar adalah jumlah mahasiswa baru fakultas ekonomi dan bisnis Islam UIN Alauddin Makassar adalah 500 mahasiwa pertahun, FEB UNISMUH Makassar rata-rata adalah 1100 mahasiswa pertahun, Universitas Islam Makassar sebanyak 300 mahasiswa jadi pertahun sumberdaya insani lembaga keuangan syariah untuk tiga institusi sebesar kurang lebih 1500 orang pertahun.

Agar alumni tersebut dapat memiliki kompetensi sesuai lembaga keuangan syariah, maka telah dilakukannya kerja sama dengan beberapa industri keuangan syariah seperti bank syariah dengan mini bank syariahnya maupun pasar modal dalam bentuk galleri investasi syariah. Hanya saja untuk pembiayaan syariah, pegadaian syariah serta asuransi syariah masih belum ada kerjasama sama sekali.sehingga ke depan dibutuhkan pengembangan kerjasama ke lembaga keuangan syariah tersebut. 


\section{PTKI Sebagai Pusat Literasi dan Inklusi Produk Keuangan Syariah}

Dalam pengembangan kompetensi ekonomi keuangan syariah di masa yang akan datang peran perguruan tinggi islam juga sangat dibutuhkan. Dimana para perguruan tinggi islam dapat menjadikan institusinya sebagai klinik keuangan syariah. Klinik ini ditujukan untuk membekali peserta yang merupakan mahasiswa maupun praktisi lembaga keuangan dengan pengetahuan dan pemahaman mengenai perkembangan terkini seputar keuangan syariah, meningkatkan kemampuan peserta menjadi trainer atau fasilitator pengajaran dan pelatihan keuangan syariah, serta memotivasi peserta untuk terlibat lebih aktif dalam pengembangan keuangan syariah, khususnya melalui pengajaran dan pelatihan keuangan syariah di perguruan tinggi.

Berdasarkan hasil pengamatan dari ke tiga perguruan tinggi islam didapatkan mayoritas mahasiswa memiliki gaya hidup yang konsumtif dan serba instan menjadikan mahasiswa sering mengeluarkan konsumsi untuk hal-hal yang sebenarnya bukan menjadi kebutuhan. Seiring perkembangan teknologi informasi yang ada mendukung mereka berperilaku serba online seperti belanja online. Penggunaan internet juga menjadikan konsumsi pulsa dan kuota menjadi lebih banyak dibandingkan dengan tanpa penggunaan internet. Oleh karena itu, salah satu upaya yang dapat dilakukan adalah dengan memberikan literasi bagi mahasiswa terkait pengelolaan keuangan yang dimiliki. Pentingnya literasi keuangan manjadi sarana dalam meningkatkan perilaku menabung mahasiswa terkait permasalahan masih rendahnya Marginal Propensity to Savings bagi mahasiswa.

Dari hasil kuisioner mengenai penggunaan perbankan syariah, terdapat 74 persen yang telah memiliki dan bertransaksi dengan produk perbankan syariah. Untuk pembelajaran di kampus yang mempengaruhi dalam penggunaan jasa perbankan syariah terdapat 68 persen yang setuju, fakultas yang menjadi fasilitator dalam penggunaan jasa perbankan syariah terdapat 78 persen yang setuju. Dari hasil ini nampak bahwa peran perguruan tinggi dalam meliterasi mahasiswa maupun masyarakat tentang keuangan syariah masih perlu ditingkatkan.

Perilaku keuangan aspek yang penting dalam edukasi literasi keuangan, karena suatu pendidikan tentunya akan lebih bernilai jika dapat membentuk perilaku peserta didik. Berbagai penelitian membuktikan bahwa edukasi dan pengetahuan keuangan baik dari sekolah maupun universitas berperan dalam perilaku keuangan peserta didik. Hasil penelitian Xiao, et al. Pada tahun 2012 menunjukkan bahwa mahasiswa yang telah melalui kursuskursus keuangan cenderung memiliki pengetahuan finansial subjektif yang tinggi yang kemudian menyebabkan mereka memiliki perilaku membayar secara berisiko yang rendah. Borden et al. menemukan bahwa mahasiswa berniat untuk berperilaku keuangan secara 
efektif dan mengurangi perilaku keuangan yang berisiko setelah mengikuti seminar literasi keuangan. Selain itu, hasil analisis oleh Shih \& Ke mengindikasikan bahwa literasi keuangan berpengaruh signifikan pada perilaku keuangan 535 mahasiswa di Taiwan (Setiawati,2014).

Selain sebagai pusat literasi, perguruan tinggi islam dapat berkontribusi dengan lebih banyak memanfaatkan layanan keuangan syariah untuk transaksi-transaksi yang sesuai, misalnya penerimaan SPP mahasiswa, pembayaran gaji dosen dan karyawan dan lain-lain. Perguruan tinggi juga dapat berkontribusi dengan memanfaatkan layanan keuangan syariah untuk pembiayaan pengadaan aset, baik yang bersifat jangka pendek maupun panjang, dengan pasar yang sudah jelas dari individu (mahasiswa, dosen dan staff) serta dari lembaga seperti kerjasama dengan koperasi pegawai.

\section{KESIMPULAN}

Penguatan peran perguruan tinggi islam dalam mendorong pengembangan lembaga keuangan syariah di indonesia dapat ditempuh melalui : 1) penyiapan sumberdaya insani yang siap pakai bagi industri keuangan syariah yaitu faham tentang ilmu ekonomi keuangan kontemporer, ushul fiqh atau fiqh muamalah melalui perbaikan kurikulum berbasis stakeholder, yaitu dengan melakukan interkoneksi kerjasama antara pelaku lembaga keuangan syariah dan pihak lainnya diantaranya Otoritas Jasa Keuangan Syariah, Dewan Syariah, Nasional Majelis Ulama Indonesia (DSN-MUI), Ikatan Ahli Ekonomi Islam (IAEI), Masyarakat dan Ekonomi Syariah (MES), untuk bersama-sama merumuskan kurikulum akademik berbasis stakeholder. Ini dimaksudkan untuk mencetak tenaga ahli yang sesuai tuntutan industri keuangan syariah. 2) menjadi media edukasi dan pengetahuan keuangan dalam perilaku keuangan peserta didik atau mahasiswa. 3) Selain sebagai pusat literasi, perguruan tinggi islam dapat berkontribusi dengan lebih banyak memanfaatkan layanan keuangan syariah untuk transaksi-transaksi yang sesuai, misalnya penerimaan SPP mahasiswa, pembayaran gaji dosen dan karyawan dan lain-lain.

\section{DAFTAR PUSTAKA}

Abduh, M., dan Sukmana, R. 2011. "Deposit Behaviour in Indonesia Islamic Banking: Do Crisis and Fatwa Matter?”. Indonesia Islamic Banking Research Forum 2011. Bandung.

Allison, Michael dan Jude Kaye. 2005. Perencanaan Strategis Bagi Organisasi. Nirlaba, Pedoman Praktis dan Buku Kerja. Jakarta: Yayasan Obor.

Karim, Adiwarman. 2005. Fiqh and Financial Analysis. Jakarta: PT. Raja. Grafindo Persada.

Lestari, Alfi Mulikhah. 2015. "Pengaruh Religiusitas, Produk Bank, Kepercayaan, Pengetahuan, Dan Pelayanan Terhadap Preferensi Menabung Pada Perbankan Syariah 
(Studi Kasus Pada Mahasiswa Fakultas Ekonomi Dan Bisnis Universitas Brawijaya Malang)”. Tesis. Universitas Brawijaya Malang.

Masruroh, Atik. 2015. "Analisis Pengaruh Tingkat Religiusitas Dan Disposible Income Terhadap Minat Menabung Mahasiswa Di Perbankan Syariah (Studi Kasus Mahasiswa STAIN Salatiga)”. Tesis. Sekolah Tinggi Agama Islam Negeri Salatiga.

Mursyid. 2011. "Preferensi Masyarakat Kota Samarinda Terhadap Bank Syariah". Nalar Fiqh, Jurnal Kajian Ekonomi Islam Dan Kemasyarakatan. Vol. 3 No. 1.

Muti`ah, Niswah. 2015. "Pengaruh Motif Rasional Dan Motif Emosional Terhadap Pengambilan Keputusan Memilih Jasa Perbankan Syariah (Studi Pada Mahasiswa Program Studi Muamalat Fakultas Syariah Dan Hukum UIN Syarif Hidayatullah Jakarta)”. Tesis. Universitas Islam Negeri Syarif Hidayatullah Jakarta.

Pearce, J. A. and Robinson, R. B. 1988. Strategic Management, Strategic Formulationand Implementation, 3rd Edition. Illinois: Richard D. Irwin Inc.

Rike Setiawati.2014. "Literasi Keuangan Syariah: Suatu Telaah Literatur”, RETURN Jurnal Ilmiah Akuntansi. Vol. 9 Edisi Juli.

Shrader, C.B., Taylor, L dan Dalton, D.R. 1984. "Strategic Planning AndOrganizational Performance: A Critical Appraisal”. Journal Of Management. Vol. 10 No. 2.

Suma, Muhammad Amin. 2008. Menggali Akar, Mengurai Serat Ekonomi \& Keuangan Islam. Ciputat : Kholam Publishing. 